\title{
Causes of informal settlements in Ekurhuleni Metropolitan Municipality: An exploration
}

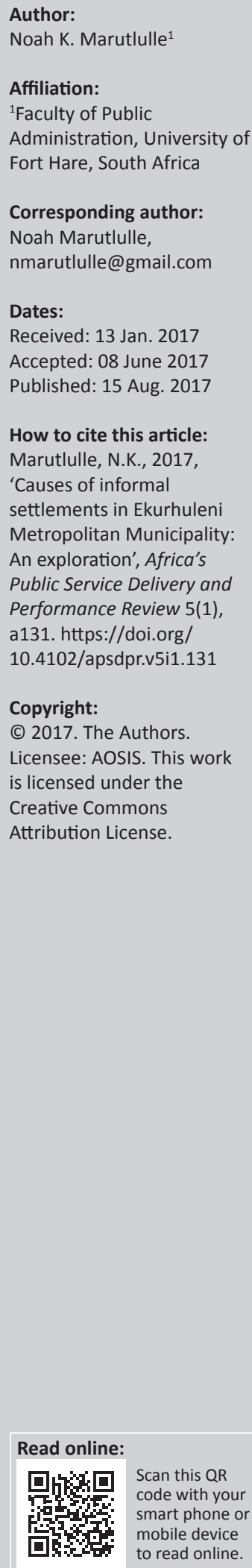

\begin{abstract}
This article aims to explore the causes of informal settlements in Ekurhuleni Metropolitan Municipality (EMM). The article strongly challenges the view that the cause of informal settlements in EMM and other parts of South Africa is predominantly the apartheid government and agrees with literature which provides evidence that to a larger extent, the present government, not the apartheid government, is one of the dominant causes of informal settlements. The article further establishes a common and fertile ground for the convergence of the different views and perspectives into variables which, in addition to the present government, include population growth, government economic policies, economic variables, housing shortage, unavailability of land and unaffordability as the real causes of informal settlements in EMM.
\end{abstract}

\section{Introduction}

Housing all over the world has remained an interdependent phenomenon that affects every facet of mankind, with its importance being so pronounced that it impacts on the social, physical and mental well-being of man, irrespective of his socioeconomic status, colour or creed (Ayedun \& Oluwatobi 2011:1). Ademiluyi (2010) states that in spite of the right to adequate housing being a universal right, recognised at international level and in more than 100 national constitutions throughout the world and also section 26 of chapter 2 of the South African constitution, the world is facing a global housing crisis. The homeless and the inadequately housed are numerous across the planet (PADCO 2006). This is corroborated by Ademiluyi, who maintains that about 100 million persons are homeless and more than a billion are inadequately housed. The problem is compounding and UN-HABITAT estimates that, worldwide, close to 3 billion people will need access to housing and basic infrastructure services over the next 25 years (Masilela 2012), which will require 35.1 million housing units per year or 96150 per day or 4000 per hour in order to meet demand. Every week more than a million people are born in or move to cities in the developing world, driving up the need for new and better housing (PADCO 2006). The estimates of the United Nations state that 3 billion persons will be living in slums in 2050 (Ademiluyi 2010).

It is therefore understandable that, lately, housing and its related issues particularly informal settlements have become a serious global problem and different countries' planners and policymakers are struggling to solve the challenges concerning the issue (Zanganeh, Varesi \& Zangiabadi 2013:180). Informal settlements represent a major challenge to development. Urban expansion and the growth of informal settlements (or slums) place great pressure on already struggling health and education systems. The University of Dublin, - Trinity College (2015) concurs, maintaining that slums place great pressure on the environment and they also pose challenges to security and social cohesion.

In Africa, failure to address housing issues has led to the continued growth of slums and poorly serviced informal settlements on the urban periphery, where between $75 \%$ and $99 \%$ of urban residents in many African cities live in squalid slums of ramshackle housing (Giddings 2007:11; Carrington 2015). The University of Dublin, Trinity College (2015) argues that Africa currently has almost 200 million slum dwellers which account for about $20 \%$ of slums around the world and as Musewe (2012) notes, Africa is the second most populous continent and with one of the highest population growth rate in the world. With its population rocketing from 1 billion in 2015 to between 3.5 billion and 5 billion in 2100 (Carrington 2015; University of Dublin, Trinity College 2015), African cities will have to accommodate more than 300 million new residents by 2030 (Masilela 2012).

Note: This article is based on a previously published article by the author Noah K. Marutlulle and co-author E.O.C. Ijeoma in this journa doi: http://dx.doi.org/10.4102/apsdpr.v3i4.101 
Like many other countries in the world, South Africa faces a growing challenge in providing all citizens with access to suitable housing. According to Statistics South Africa's Household Survey 2011, 12.1\% (1 789 million households) of South Africa's 14.75 million households lived in informal housing in 2011 with Gauteng having 20.4\% households living in informal settlements, North West $18.5 \%$ and the Western Cape 15.1\%. Limpopo has the smallest percentage with $4.5 \%$ and the Eastern Cape has 6.5\% (South Africa year book 2012/13:347).

When the present government assumed power in 1994, the majority of South Africans, particularly disadvantaged ones in the black community, Indian community and mixed race community believed that life would change for the better and service delivery, particularly for essential services, with housing at the apex, would be improved. They believed that the unequal and separate coexistence of population groups across the country, which was inextricably connected with the structure and functionality of the previous government regime, would finally come to an end. This was heightened by the government's promises of the provision of free housing and free basic services which encouraged an entitlement mentality and a dependability syndrome that reduced rather than encouraged an impetus to self-help (Jeffery 2010:351) and caused an exponential surge in the expectation of free benefits from government largesse.

Many years later, for hundreds of thousands of people in Ekurhuleni, the so-called urban underclass, a place to call home remains an elusive dream (Lindsell 2007:81). With the house being a place helping to meet the basic physiological needs and helping man to maintain his life (Hablemitoglu, Ozkan \& Purutcuoglu 2010:214), there are still people in the municipality who do not benefit the most basic of services who do not even have decent living conditions, with some resorting to providing their own shelters (shacks) in a spontaneous and unplanned way, sprawling informal settlements (squatter camps). This assertion is corroborated by Streek (2001:5) who maintains that as a result of the shortage of adequate and available shelter, people occupy any vacant land they find and put up shacks in areas without sanitation, infrastructure or social amenities. According to (Baloyi 2007:1), this instigates public demonstrations, some of which are rambunctious and extremely violent as communities feel betrayed and let down by the government and its representative bodies, particularly municipalities.

This article provides that the issue of informal settlements will remain a serious one for Ekurhuleni Metropolitan Municipality (EMM), provincial and national government unless it is seriously investigated and efforts have been made towards its resolution at municipal level. This is because EMM is the conduit that links the people to provincial and national government and is crucial in coordinating government programmes (Hablemitoglu et al. 2010:214). Government initiatives reach the people via EMM which is closer to the people and would understand much better the peoples' needs and challenges. Nathan (2013) concurs and states that municipalities are better positioned to know what people need as municipalities are institutionally closer to communities, hence decision-making can be more participatory through the council system and policies can be applied more effectively at the municipal level than at the national level. Mhone and Edigheji (2003:146) maintain that housing is a concurrent competence of municipalities while Van Der Waldt and Du Toit (1997:147) state that municipal is the level of government more than any other level that determines the nature and environment within which individuals find themselves. Moreover, setting metropolitan delivery goals and identification and designation of land for housing purposes are functions envisaged to be performed at metropolitan and or local level (White paper on housing 1994:31).

This paper has a comprehensive one-dimensional purpose. It seeks to broaden the inquiry into causes of informal settlements in EMM and, by so doing, provide a solid baseline of information on informal settlements relative to the housing delivery challenges experienced in EMM and dissipate perceptions in existence surrounding the problem. These are that political science and law scholars attribute the existence of informal settlements in the country including EMM entirely to the apartheid government and its pass laws, while environmental management and geography scholars attribute same to environmental degradation caused by dolomite mining (A'bear 2012; Deedee 2011; Storie 2011). This paper strongly opposes the apartheid view

\section{Definitions for informal settlements}

There are a number of definitions that are attached to informal settlements. Some of them are summarised in Table 1.

While there are some variances across the foregoing definitions depending on context, what is prominent holistically is the emphasis on the dwelling type: temporary structures or dwellings that are built out of rudimentary materials as a dominant feature of informal settlements. In addition, all the definitions refer to lack of ownership of the land, the nature of land tenure and formal demarcation. This is in line with the United Nations definition: according to The University of Dublin, Trinity College (2015), informal settlements are living conditions (shacks, squatter camps and slums) which lack at least one of the basic conditions of basic housing - adequate sanitation, improved water supply, durable housing or adequate living space. This is the definition which is consistent with this article.

There are also a number of names by which informal settlements are described at social and organisational levels depending on a variety of defining parameters which emanate from 'squatter camps' and, as Srinivas (1991) states, highlight the attitudes and approaches towards them, ranging from positive to neutral to negative outlooks. These are:

- slums

- low-income settlements

- semi-permanent settlements 
TABLE 1: Definitions of informal settlements.

\begin{tabular}{|c|c|}
\hline Source & Definition \\
\hline HABITAT III issue papers & $\begin{array}{l}\text { Residential areas (squatter camps) where inhabitants have no security of tenure for the land, they lack basic services and the housing may not comply } \\
\text { with current planning and building regulations. They are often situated in geographically and environmentally hazardous areas (UN Habitat 2015:1). }\end{array}$ \\
\hline Encyclopedia Britannica & $\begin{array}{l}\text { Residential areas that are physically and socially deteriorated and in which satisfactory family life is impossible, where bad housing - which refers to } \\
\text { dwellings that have inadequate light, air, toilet and bathing facilities; that are in bad repair, dump and improperly heated; that do not afford opportunity } \\
\text { for family privacy; that are subject to fire hazard and that overcrowd the land, leaving no space for recreational use - is a major index (Srinivas 1991). }\end{array}$ \\
\hline SRINIVAS & $\begin{array}{l}\text { residential area (squatter camp) which developed without legal claims to the land or permission from the concerned authorities to build; as a result } \\
\text { eir illegal or semi-legal status, infrastructure and services are usually inadequate (Srinivas 1991). }\end{array}$ \\
\hline Statistics South Africa & structures not approved by a local autnority ana not intenaed as a permanent aweiling) (Ine no \\
\hline $\begin{array}{l}\text { City of Tshwane } \\
\text { Metropolitan } \\
\text { Municipality }\end{array}$ & $\begin{array}{l}\text { One shack or more constructed on land, with or without the consent of the owner of the land or the person in charge of the land. 'Shack' means any } \\
\text { temporary shelter, building, hut, tent, dwelling or similar structure which does not comply with the provisions of the National Building Regulations and } \\
\text { Building Standards Act, } 1977 \text { (Act } 103 \text { of 1977) (The housing development agency 2013:7). }\end{array}$ \\
\hline $\begin{array}{l}\text { City of Johannesburg } \\
\text { Metropolitan } \\
\text { Municipality }\end{array}$ & $\begin{array}{l}\text { An impoverished group of households who have illegally or without authority taken occupation of a parcel of land (with the land owned by the council in } \\
\text { the majority of cases) and who have created a shanty town of impoverished illegal residential structures built mostly from scrap material without provision } \\
\text { made for essential services and which may or may not have a layout that is more or less formal in nature (The housing development agency 2013:7). }\end{array}$ \\
\hline $\begin{array}{l}\text { Ekurhuleni Metropolitan } \\
\text { Municipality }\end{array}$ & $\begin{array}{l}\text { he unauthorised occupation of land. In addition, the use of the land may be unauthorised, and in most cases the construction standards do not comply } \\
\text { ith building regulations (The housing development agency 2013:7). }\end{array}$ \\
\hline
\end{tabular}

- shanty towns

- spontaneous settlements

- unauthorised settlements

- unplanned settlements

- uncontrolled settlements.

\section{Squatter camps}

The term 'squatter' has a specific connotation which implies that the residents have no legal right to the land on which they build their shacks or shanties (Power 1993:189). The only land available to them is waste or unwanted land which most often is unused because of environmental problems such as the extremes of flooding or water shortage or steepness of slope (Carter 1990:138). This is in line with Tshitekere's (2008) view that the magnitude of this spatial dysfunctionality is clear at social, economic and ecological levels, which remain deep and enduring and attributes this to settlements that are often located on barren grounds, on pavements, along rivers and canals, in areas prone to floods and other hydro-meteorological hazards, on extremely insalubrious sites with health hazards such as sewage outlets, near or on dump sites and in areas with little access such as alleys and corridors of buildings - even on rooftops. Barry (2003:5) states that a massive urban-ward migration of population which the employment opportunities available cannot absorb is one characteristic of the less developed world. More significantly in the present context, the housing available is also totally inadequate and the municipalities cannot from their resources meet the enormous demand resulting in the immigrants simply squatting on whatever land is available and bringing into being enormous squatter or spontaneous settlements (Carter 1990:138).

In light of the foregoing, Srinivas (1991) states that there are essentially three defining characteristics that help in the comprehension of squatter settlements. These are:

1. Physical characteristics: these pertain to the lack or inadequacy of basic services like water supply, sanitation, electricity, roads and drainage, schools, health centres, market places, etc.

2. Social characteristics: these pertain to the fact that squatters are predominantly migrants, either rural-urban

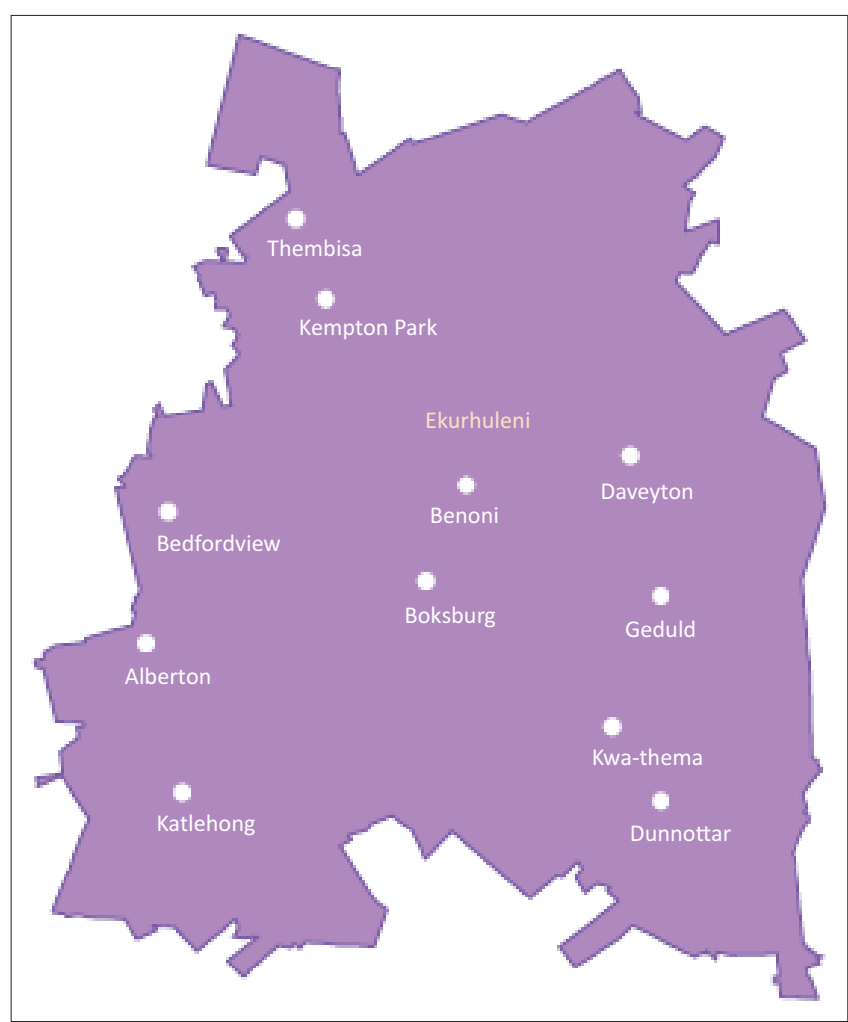

Source: City of Ekurhuleni Annual Report (2010/11:2)

FIGURE 1: Map for Ekurhuleni Metropolitan Municipality.

or urban-urban and some are second- or third-generation squatters.

3. Legal characteristics: these refer to the key characteristic that delineates squatter settlements as their lack of ownership of the land parcels on which the squatters would have built their houses.

\section{Ekurhuleni Metropolitan Municipality}

Ekurhuleni Metropolitan Municipality is one of the fastest growing areas in South Africa (IDP \& SDBIP 2013/14). With its establishment having resulted from the restructuring of local government in 2000, it forms the local government of East Rand, the capital of which is Germiston and which is made up of nine towns, as depicted in Figure 1, including 
Germiston, Alberton, Benoni, Boksburg, Brakpan, Kempton Park/Tembisa, Edenvale, Nigel and Springs. It is one of the six districts of Gauteng province and one of the eight metropolitan municipalities of South Africa.

The Ekurhuleni Metropolitan economy is larger and more diverse than those of many of the smaller countries in Africa and accounts for nearly a quarter of the Gauteng economy. About $7 \%$ of the country's spending power and $7.4 \%$ of the nation's production is located in this area (City of Ekurhuleni Annual Report 2010/11:7). Many of South Africa's factories for production of goods and commodities are located in Ekurhuleni where manufacturing accounts for just less than $20 \%$ of the gross domestic product of Gauteng. It boasts huge manufacturing industries such as iron and steel, fabricated and metal products, food, machinery, electrical machinery, vehicles parts and chemical products. It is regarded as the transportation hub of the country (Ekurhuleni Metropolitan Municipality - Intergrated Development Plan and Service Delivery Budget Implementation Plan, 2015).

The municipality is home to the OR Tambo International Airport, the busiest airport in Africa, which services the entire continent and links to major cities throughout the world. South Africa's largest railway hub is in Ekurhuleni (Germiston) and links the city to all the major population centres and ports in the southern African region (IDP \& SDBIP 2013/14). The Blue IQ projects situated within Ekurhuleni include the Wadeville-Alrode Industrial Corridor with linkages to the largest logistical hub, the City Deep Container terminal, the Gautrain rapid rail link to Johannesburg and Tshwane and the OR Tambo International Airport Industrial Development Zone (IDZ). All this makes it a potential target for employment seekers from inside and outside the country.

Ekurhuleni Metropolitan Municipality suffers a high continued demand for housing. In the post-1990 period, densification of the urban areas led to Ekurhuleni being a highly concentrated urban complex presently housing the largest number of informal settlements in Gauteng. According to City of Ekurhuleni Annual Report (2010/11:7), many of the informal settlements are situated on land unsuitable for housing and well-located land suitable for housing development is not readily available. A total of 66 informal settlements are currently located in areas not suitable for development and were earmarked for relocation by the Department of Human Settlements. There are large vacant land parcels in the mining belt around the urban core which cause Ekurhuleni's spatial distribution to be fragmented. This has resulted in an inequitable city and low-development densities, with historically disadvantaged communities situated on the urban periphery (IDP \& SDBIP 2013/14).

\section{Extent of informal settlements in Ekurhuleni Metropolitan Municipality}

With a total surface area of 1928 square kilometres, a population of 3.2 million and 896117 households, the population of approximately 1650 people per square kilometre makes EMM the most densely populated city in Gauteng province - with a population that constitutes 5.6\% of the national population and $28 \%$ of Gauteng's population (City of Ekurhuleni Annual Report 2010/11:7). EMM has a huge housing backlog with 134000 shacks in 122 informal settlements and 360000 backyard shacks (Ekurhuleni Metropolitan Municipality - IDP and SDBIP 2015). The backlog is ever-swelling and EMM is struggling to cope with the severe housing shortages which can be likened to chasing a moving target. City of Ekurhuleni Annual Report (2010/11:6) suggests that assuming the current average growth rate of $3 \%$ per annum, by the year 2025, approximately 1650595 people will need to be housed, which will translate to increased densities as the current figure of 1650 people per kilometre will increase to 2172 people per kilometre.

Of the 122 informal settlements within its urban fabric, $20 \%$ are upgradable and $80 \%$ which accommodates more than 400000 of its residents has not been targeted for redevelopment, given that there is inadequate resource availability (Ekurhuleni Metropolitan Municipality - IDP \& SDBIP 2015).

According to then EMM MEC for Human Settlements Councillor Queen Duba, between 2000 and 2012, 94969 houses were built (Harrison 2013). This means that an average of 8081 houses were built per year. At this rate, and with a housing backlog of 365 672, this would mean that it would take another 45.2 years before the current backlog within the Ekurhuleni Metro is addressed. This calculation excluded the growth in demand, which was sure to result from the natural population growth and the ongoing influx of people into the city.

\section{Causes of informal settlements in Ekurhuleni Metropolitan Municipality}

According to UN-Habitat (2015:2), informal settlements are caused by a range of interrelated factors, including population growth and rural-urban migration, lack of affordable housing for the urban poor, weak governance (particularly in the areas of policy, planning, land and urban management resulting in land speculation and grabbing), economic vulnerability and underpaid work, discrimination, marginalisation and displacement caused by conflict, natural disasters and climate change. Innes, Kentridge and Perold (1992:171) maintain that the increased mobility of informal dwellers and the rapid formation of shanty towns have been facilitated by administrative confusion, institutional restructuring and the absence of clear policy, all of which have left a vacuum in which squatter settlements have been able to flourish.

This paper is of the view that informal settlements in EMM are predominantly caused by factors that cause housing delivery challenges and demonstrates that causes of informal settlements are intertwined with causes of housing delivery. These are:

- the apartheid government

- population growth (migration, urbanisation and demographics) 
- government economic policies [Reconstruction and development programme (RDP), Growth, employment and redistribution (GEAR) and Accelerated and shared growth initiative (ASGI-SA)]

- administrative issues (municipal maladministration, lack of control and corruption)

- economic variables (poverty, unemployment, unaffordability and poor access to housing finance)

- housing shortage

- unavailability of land

- unaffordability.

\section{The apartheid government}

Cloete (1995:35) posits that the present government faced great difficulties and enormous backlogs because of the apartheid legacy. This was corroborated by Malpass (1990:5) in his view that the apartheid state's lack of investment in housing created an unprecedented housing shortage and resulted in the proliferation of squatter camps. According to Barry (2003:10) then, massive overcrowding was inevitable. For instance, in Katlehong (a township in EMM), population density in the 1980s stood at 23-30 per stand and a survey conducted in Thokoza in 1988 found an incredible 16-20 households crammed on to each stand (Bonner, Nieftagodien and Mathabatha 2012:152).

While the foregoing facts are indicative that the extent of the present informal settlements challenges derives not only from the enormous size of the housing backlog and the desperation and impatience of the homeless, but stems also from the extremely complicated bureaucratic, administrative, financial and institutional framework inherited from the previous government (White paper on housing 1994:1). The African National Congress (ANC 1994:23) admits that the housing problems created by apartheid were however aggravated by the absence of a coherent national housing policy, post apartheid. While Eddy (2010:3) affirms that historical circumstances continue to affect service delivery, Brutus (2002:1) however argues that the problems confronting many citizens today including those in EMM are not simply the result of historical factors - the housing crisis and other basic services is in essence a result of the pro-market policies adopted by the South African government since 1994. This assertion was corroborated by May, Carter and Padayachee (2004:18) and Mhone and Edigheji (2003:23) who alluded that the present government's policies resulted in reductions in the budget deficit and inflation against the backdrop of diminished expenditure allocations to social votes including housing. Moreover, in the period just before the end of apartheid rule, home ownership was regarded as something of a capitalist trap by many Black unions who feared that it might engender more conservative ideologies among union membership (Innes et al. 1992:117).

\section{Population growth}

Most of the challenges that seemingly remained unresolved since 1994 were as a result of EMM among other municipalities chasing moving targets (Bonner et al. 2012:176). Jeffery
(2010:353) attributes this to inter-provincial migration and the splitting of households into smaller entities. However, Napier (1993:23) argues that the rate of population growth is more a function of natural growth than other aspects such as in-migration to urban areas. Despite stringent influx control measures to curb African urbanisation, Ekurhuleni's population grew steadily towards the end of apartheid (Bonner et al. 2012:150).

Ekurhuleni's dynamic economic development made it an important destination for work-seekers. From the time the first mine started operating and the first mining villages developed, prospective miners and labourers and entrepreneurs streamed to the region in search of work or fortune (Bonner et al. 2012:117). Urban areas were created to provide places to live and work for people who could no longer make a living from farming or wanted to do something other than farming. It is accepted that urban areas which came to be known as cities or towns were the cradles of civilisation because they served as havens for persons who wanted to invent and manufacture goods which could enable mankind to improve their quality of life (Cloete 1997:43). In the period after 1960, the lack of affordable industrial space in Johannesburg, the country's largest city, meant that many companies wishing to expand their operations during the boom times were forced to relocate to areas outside Johannesburg. About $83 \%$ of these firms set up their new plants in Ekurhuleni, especially in the industrial areas of Kempton Park, Germiston and Alberton (Bonner et al. 2012:119).

The almost insatiable demand for labour by the rapidly expanding secondary industry (mining) attracted hundreds of thousands of African workers into Ekurhuleni, a city that is deemed to lack a clear city identity and is instead characterised by multiple urban identities (Bonner et al. 2012:198).

The influx of foreigners (both legal and illegal) into Gauteng from drought-stricken and strife-torn nations in other parts of sub-Saharan Africa compounds the problem, with the majority of them opting to move into EMM as it is the industrial hub of Gauteng with better job prospects. Eddy (2010:3) agrees that the phenomenon of territorial human mobility continued to place a greater strain on services which led to higher proportions of people living in informal settlements.

Natural increase of the population as argued by Napier (1993:2) is another straining factor. The rate of natural increase is highest among the poorest communities, which means that the poor will constitute an ever-increasing proportion of the total urban population over the next decades (Napier 1993:22). According to Van Der Waldt and Du Toit (1997:380), issues arising from population growth are related to the capacity of South Africa's limited resources to provide for the peoples' needs and that it (population growth) has a ripple effect on the provision of services including housing. From 1995 to 2005 for instance, the number of 


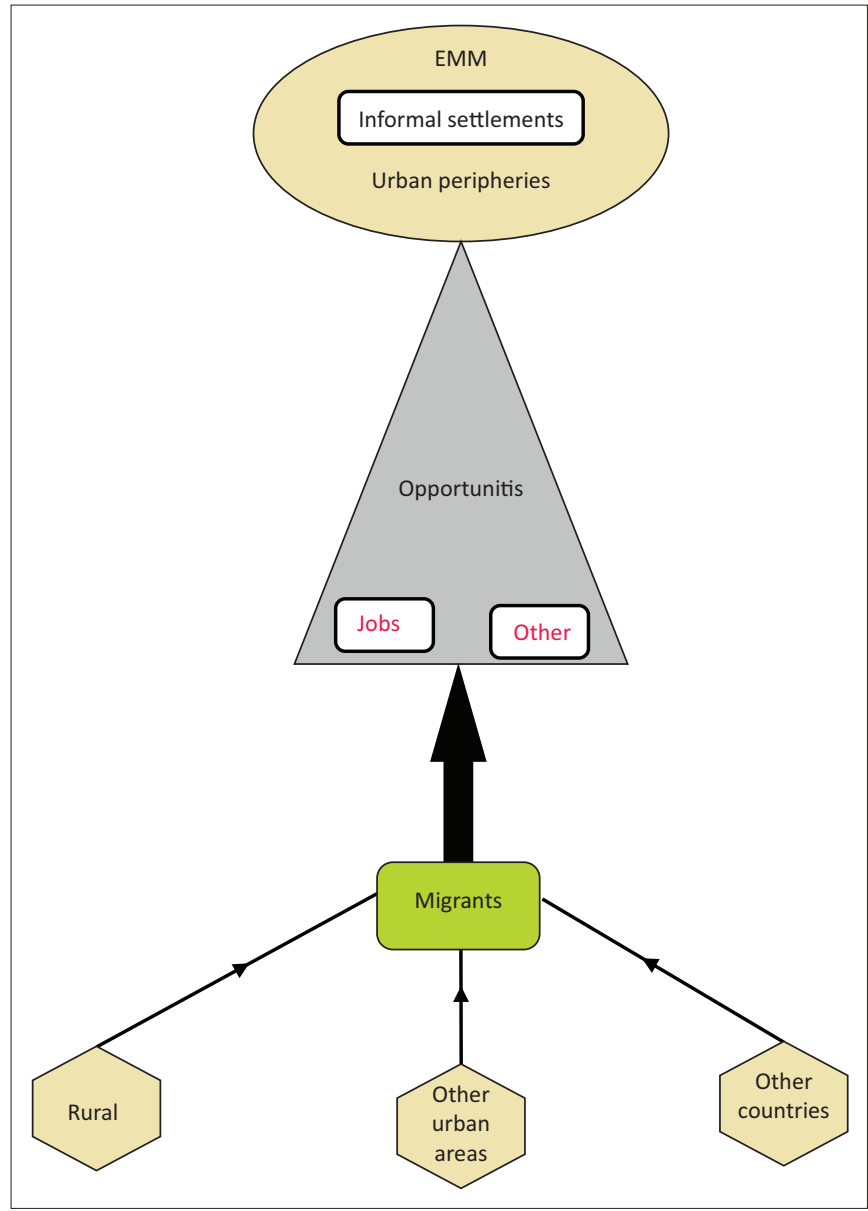

FIGURE 2: Migration into Ekurhuleni Metropolitan Municipality.

households rose by $45 \%$, making it difficult for the municipality to keep pace with demand despite an impressive delivery of RDP homes (Jeffery 2010:353). Mhone and Edigheji (2003:60) concur that progress is being made on the housing front but admit that the backlog far outruns the construction and delivery of housing.

\section{Migration into Ekurhuleni Metropolitan Municipality}

The rapid expansion of cities throughout the world has been accompanied by equally rapid growth of informal settlements often known as slums (The University of Dublin, Trinity College 2015). Slums develop as the formal housing market is unable to cater for the number of migrants, many of whom are extremely poor. EMM fails to cope with housing demand set up by the massive influx into the municipality. The locations taken up by these newcomers to the city can be set out in the form of a diagram which also indicates the dynamic process involved (Figure 2). The city centre (EMM) with its perceived concentration of job and other opportunities is the preferred location and, as in the developed world, the predominant movement of low status immigrants is to the inner city - but that area is incapable of assimilating the numbers. Moreover, at the centre with growth, commercial and associated uses are extending and rents are rising so that many of the inner-city residents are forced out towards the periphery. People in the lowest social groups are displaced outwards just as many of the new immigrants move directly to these squatter settlements at the margin (Carter 1990:138). As depicted in the diagram, there are three types of migrants who infiltrate into EMM most of whom either form informal settlements or add to the existing inhabitants of informal settlements:

1. from rural areas

2. from other urban areas

3. foreigners - both legal and illegal.

Emphatically, the foregoing suggests that migration of people to EMM is not solely job seeking. Other reasons for migration into the city which are often regarded as potential 'pull' factors promoting in-migration to EMM include infrastructure such as health facilities, medical services, education and social security.

\section{Urbanisation}

In general, the expansion of the towns of Ekurhuleni mirrored the broader national process of urbanisation (Bonner et al. 2012:117). Urbanisation is the change in the proportion of a population living in urban places or areas (Weeks 2012:357) or a social change on a vast scale, which means deep and irrevocable changes that affect all sectors of society (Brutus 2002:3). Jiboye (2011:177) provides that urbanisation is the process of human agglomeration in multifunctional settlements of relatively substantial size. In this process a particular society shifts from being largely bound to the country to being bound by the city. Napier (1993:25) views it as a spontaneous phenomenon of in-migration to cities which requires creative management. The process is irreversible once it has begun. Urbanisation is one of the factors that has resulted in the unprecedented increase in the populace of $\mathrm{EMM}$ and is one of the contributors to housing delivery challenges in the metropolitan municipality which ultimately cause informal settlements.

Urbanisation has grown far beyond the economic growth pace of EMM which failed to accommodate the increased population and that imbalance between economic growth and urbanisation resulted in the spiralling of informal settlements (in the form of slums or squatter camps) (City of Ekurhuleni 2011:16) - the negative residual of economic growth and urbanisation equation. This means that EMM does not have sufficient economic capacity to accommodate the needs of its urban population (Knight 2002).

\section{The democratic government Government's promises of free housing}

The dawn of a democratic order in 1994 promised not only to finally end the discriminatory policies of apartheid but equally importantly to transform the lives of millions of oppressed South Africans (Bonner et al. 2012:198). Expectations were heightened by the fact that when the present government came into power (in 1994), one of the electoral promises it made was that it would endeavour to build a house for every South African (Bradley 2003:85). This is in line with ANC's (1994:23) emphasis that housing must 
be affordable to even the poorest of South Africans. However, Jeffery (2010:355) argues that the constant emphasis on the government's role in delivering free housing to the poor sapped an impetus to self-help and bred a strong dependency on the state. Following the heightened expectation, there was a massive mobility of people from different parts of the country into EMM who decided to await the delivery of free houses in informal settlements.

\section{Government economic policies}

While several research studies (Barry 2003:2; Bonner et al. 2012:145; Cloete 1995:35; Eddy 2010:3; Malpass 1990:5) maintain that the present government is facing great difficulties and enormous backlogs because of the apartheid legacy to which they solely attribute the present housing delivery challenges that contribute to the sprawling of informal settlements, Brutus (2002:1) argues that the problems confronting many citizens including those in EMM are not simply the result of historical factors. The crisis of housing delivery and other basic services is actually a result of the pro-market (growth-oriented) policies adopted by the South African government since 1994, a primary goal of which was to reduce inflation and government spending to below $4 \%$ of the gross domestic product, thereby limiting the amount of money the government could spend on social needs including housing (Bradley 2003:85). According to Bond and Tait (1997:19), the housing situation was aggravated by systemic problems in the market-based housing provision systems exacerbating housing inequalities and resulting in informal housing. It is the view of Bonner et al. (2012:207) that from the mid-1990s, South Africa's economic policies were firmly framed within a neo-liberal paradigm, which as critics (Bond 2002; Bradley 2003; Datt 2002; Dyantyi 2007; Habitat \& ILO 1995; Harvey 2000; Khan \& Thring 2003; Knight 2002) point out is characterised by the expansion of opportunities and options for private capital accumulation. Habitat and ILO (1995:1) concede by confirming that in many countries, it has been the policies adopted in response to macroeconomic trends rather than the trends themselves that have resulted in significant declines in shelter investment and a worsening of housing and infrastructure conditions.

Jeffery (2010:255) concurs with Bradley's (2003:85) argument that the present government has to a certain extent contributed to the current housing delivery challenges encountered by EMM which resulted in the sprouting of informal settlements via its growth aligned policies including the RDP - aimed at alleviating poverty and reconstructing the economy-GEAR - aimed at rebuilding and reshaping the economy in keeping with the goals of the RDP-and ASGI-SA aimed to help the state to attain its core objectives of halving poverty and unemployment by 2014 , a target which was grossly missed. Bhorat and Cassim (2004:21) agree that since 1994, government introduced policies aimed primarily at creating an environment conducive to growth. May et al. (2004:18) and Mhone and Edigheji (2003:23) assert that the GEAR economic strategy that was released by government in 1996 as a macroeconomic framework for growth and development resulted in reductions in the budget deficit and inflation against the backdrop of diminished expenditures in social votes including housing. According to Jeffery (2010:239), while the RDP, which had among its focus areas projects aimed at meeting basic needs such as the construction of a million low cost houses and the extension of electricity and piped water to people without them, government expenditure was not to be increased to meet the costs of the projects. ANC (1994:23) maintains that one of RDP's first priorities was to provide housing for the homeless - a human right. The resources used to finance the ASGI-SA strategy which was intended to help the state attain its core objectives of halving poverty and unemployment by 2014 also resulted in a decrease in funds intended for social needs, including housing (Jeffery 2010:88). In agreeing with the foregoing assertion, Setplan (2008:38) opines an example substantiating government policies aggravating housing delivery challenges by stating that the trend of informal settlements continuing to grow and appearing on urban peripheries is exacerbated by policies that promote freehold, single units per 'erf' like the RDP. It is unfortunate that such challenges can only be arrested at national level not by EMM.

\section{Administrative issues}

Municipal maladministration, lack of control and corruption are the main administration-related factors that cause housing challenges and ultimately informal settlements. However, according to Harrison (2013), despite these factors, the ANC continues to mislead desperate EMM residents with promises of houses in order to win their votes.

\section{Municipal maladministration}

According to Robbins et al. (2008:20), it is hard to get high performance from public servants because they are generally lazy, more security oriented and less motivated. This is also applicable to EMM employees. Some of them from departments that deal with the allocation of government houses have played a contributory role and continue to play a contributory role to the continuing housing delivery challenges encountered in EMM by being inefficient and ineffective (Jeffery 2010:239). Others aggravate the situation by involving themselves in corrupt activities that enrich themselves (Nathan 2013) at the expense of the metropolitan municipality as substantiated below.

\section{Corruption}

According to Cloete and Mokgoro (1995:137), corruption is a particularly viral form of organisational cancer which, once it enters the life stream of a public agency, quickly spreads to all parts - it is highly contagious, debilitating and costly to treat. Corruption also hinders delivery of affordable housing. According to Nathan (2013), because of the hierarchical character of the state and the related lack of accountability of high-level officials to their subordinates and the general 
public, 'shady' tender deals with private firms and outright theft of state funds and property is the norm.

In EMM some staff members are involved in corrupt activities which lead to, among other variables, people not on housing waiting lists or people who do not qualify for government houses, like foreigners, being granted preference in the allocation of houses. Such conduct contradicts Cloete's (1997:69) assertion that every public official should display a sense of responsibility when performing official duties, in other words, the conduct should be above reproach. Corruption has become widespread, particularly in the granting of housing subsidies, the selection of building contractors and allocation of completed RDP houses (Jeffery 2010:354). Between February 2010 and January 2012, 63 EMM officials had charges of fraud and corruption levelled against them (City of Ekurhuleni Annual Report (2011/12:227).

Burger (2010:2) states that in April 2010, then Minister of Cooperative Government and Traditional Affairs, Mr Sicelo Shiceka, admitted that municipalities were riddled with corruption and maladministration. However despite the admission, no effective measures are put in place to eradicate corruption (Jeffery 2010:354). Ekurhuleni communities are suffering as a result of this.

\section{Lack of control}

Control is strongly linked to accountability (Craythorne 1993:263). Lack of it leads to apathy, mismanagement and incompetence. According to Stoner, Freeman and Gilbert (1995:558), control is the process of ensuring that actual activities conform to planned activities. Van Der Waldt and $\mathrm{Du}$ Toit (1997:360) define it as a process of monitoring activities to determine whether individual units and the institution itself are obtaining and using their resources efficiently to achieve their objectives. Du Toit, Erasmus and Strydom (2007:230) concur and further maintain that control is applied to ensure that the organisation's resources are deployed in such a way that the organisation reaches its goals and that if there is no control, the organisation's resources could be wasted or misapplied. An organisation may formulate correct plans and policies but underperform or malperform because of a lack of necessary controls (Craythorne 1993:263). This is commonplace with EMM.

\section{Economic variables}

Poverty, unemployment, unaffordability and poor access to housing finance are the general factors that, combined, make up the economic variables. While the private sector has been trying to service the populace that falls within its ambit with the construction and provision of houses, it is not sufficiently coping (Cloete 1997:69), leaving those that have not been serviced for one reason or other (for example, not being eligible because of having an unfavourable credit history, having been blacklisted or unable to afford) to increase the volumes that are dependent on government for the supply of houses and some to spill into informal settlements.

\section{Poverty}

In general, the poor are inadequately housed (Baloyi 2007:1). The South African society is largely characterised by extreme poverty (Steenekamp 2012:124), which is the leading social issue in the continuation of sprawling cities. The rate of natural increase is highest among the poorest communities, which means that the poor will constitute an ever-increasing proportion of the total urban population for many years to come (Napier 1993:22). However, this is contradicted by City of Ekurhuleni Annual Report (2011/12:177) as per Table 2 showing the poverty status in Ekurhuleni reflecting a year-on-year decline in the periods 2009, 2010 and 2011 successively.

As Sokupa (2009:1) states, government has the responsibility to make policies and laws about the rights and responsibilities of citizens and the delivery of government services. It collects revenue (income) from taxes which it is supposed to use to provide services and infrastructure that improve the lives of all the people in the country, particularly the poor. At present, millions of South Africans face severe problems in accessing even the most basic services and according to Sokupa (2009:1), many of these ultimately become matters of life and death, particularly with regard to issues of housing. More than 1 million families still live in shacks without power, often sharing a single tap and a mobile toilet among dozens of informal households (Steenekamp 2012).

In many areas of Ekurhuleni, where according to Ekurhuleni Metropolitan Municipality - IDP \& SDBIP (2015), the poverty magnitude is $28.3 \%$ and where shack dwelling is befittingly synonymous with poverty, the situation is worse with most of the shack dwellers being evicted by authorities and having their shacks and property destroyed. They are forced to move to new areas where they face even more evictions. The poor are ignored by policymakers only to become the focus of public concern when they threaten property interests or when shacks are demolished (Innes et al. 1992:165). It is thus at moments of stress that the existence of the poor or urban homeless penetrates the public consciousness.

\section{Unemployment}

Increasing unemployment is one of the causes of informal settlements (Nathan 2013:1). The housing development agency (2013:24) concurs in their statement that unemployment rates are noticeably higher in informal settlements and that this is consistent with informal settlements acting as 'arrival cities' accommodating those seeking an entry point into the labour market. This is the situation in EMM where according to Ekurhuleni Metropolitan Municipality - IDP \& SDBIP (2015), the rate of unemployment is $30.7 \%$.

TABLE 2: Poverty status in Ekurhuleni.

\begin{tabular}{lccc}
\hline Year & Population & Number of poor people & Share of people in poverty \\
\hline 2009 & 2844706 & 774596 & $27 \%$ \\
2010 & 2873997 & 752317 & $26 \%$ \\
2011 & 2902008 & 709382 & $24 \%$ \\
\hline
\end{tabular}

Source: City of Ekurhuleni Annual Report (2011/12:31) 
Barry (2003:5) maintains that a massive urban-ward migration of population which the employment opportunities available cannot absorb is one characteristic of the less developed world.

\section{Unaffordability}

Unaffordability refers to the negative relationship between income and house prices. According to the 2011 Census, 69\% of households in shacks in Gauteng province, which EMM is a major part of, have a household income of less than R3500 per month, with $42 \%$ earning less than R800 per month (The Housing Development Agency 2013:25). Coupled to the other key contributory factors to housing delivery challenges in EMM is unaffordability by individuals (White paper on housing 1994:9). Low income, particularly among the R2500 - R7500 income group is the contributing factor to unaffordability (South Africa Survey (2008/9:582). This is in line with the assertion by the Provincial Budgets and Expenditure Review (2010:69) that in metropolitan areas, the house price to income ratio increased from a stable average of approximately 2.7 between 1996 and 2000 to 5.2 in 2005 (getting worse as the years progress), which substantiates the reality that housing has become less affordable. These low incomes of large proportions of South Africa's population imply that many people are unable to afford adequate housing using their own financial resources alone (White paper on housing 1994:9). Fife (2007:36) concurs and maintains that it has become far more difficult for low income earners to get onto the property ladder. Innes et al. (1992:181) propounded a view that socioeconomic realities are such that even the most modest formal house is beyond the reach of the poor, the majority of whom live in informal shelters. Jeffery (2010:354) concedes in his statement that the minimum government housing subsidy has been eroded by building inflation and banks are not extending mortgage finance to the very poor who cannot afford even the cheapest and most rudimentary formal dwelling, which leaves informal settlements as their only alternative.

\section{Poor access to housing finance}

Housing finance from financial institutions is key to the development of the primary and secondary housing market (Department of Housing 2004:4). One feature common to all informal dwellers is poor access to financial assistance in the form of loans for formal housing and serviced sites or housing subsidies by employers (Innes et al. 1992:179). Banks have previously been reluctant to invest in townships or new low-cost housing developments mainly because of negative perceptions about crime and repayment risks (Bradley 2003:85). The Home Loan Disclosure Act which was designed to allow the government to monitor trends within banks was drawn up in response to claims that banks have, in the past, been treating black people and low-income earners with prejudice (Bradley 2003:85). With the housing market currently being driven by first-time buyers and the average house price increasing by $3.2 \%$ month-on-month to R665 167 (South Africa year book 2012/13:347), the number of people migrating into informal settlements is set to further plummet.

\section{Housing shortage}

At the centre of the informal settlements problem, is the housing problem which is caused by drastic shortage of housing. Housing shortage means that the total number of households exceeds the number of dwellings available (Malpass 1990:5). The shortage of housing in EMM is also attributed to the unavailability of land. Efficient assembly and release of appropriately located land for housing is critical to achieving the desired rate of delivery of housing (White paper on housing 1994:27) to arrest the problem of informal settlements.

Adequate shelter means more than a roof over one's head (Bradley 2003:3). It means adequate privacy, space, security, lighting and ventilation, basic infrastructure and location with regard to work and basic facilities - all at a reasonable cost (Habitat \& ILO 1995:2). Inadequate housing can be manifested in many forms which may appear individually or in combination and may be regarded locally as a problem or may not be (Harvey 2000:28). Crowding or inadequacy of space either in terms of area or in the number of separate rooms is a common sign of inadequate housing (Habitat \& ILO 1995:2).

As Bradley (2003:85) succinctly puts it, as prevalent as inadequacy of space and probably more dangerous is the lack of services available to large numbers of people in urban housing. The lack of a clean water supply or a means of safe disposal of human, domestic and clinical and industrial waste contributes to morbidity and mortality on a massive scale (Habitat \& ILO 1995:3). It is undoubtedly true that in general the poor are inadequately housed and that the poorer a country is, the less adequate are housing conditions, at least in the low income groups (Baloyi 2007:1) However, as Habitat \& ILO (1995:3) put it there are so many variables (traditional building methods, legality of low-cost technologies in urban areas, availability of land, proportion of income just spent on food) that such a generalisation can only be the most crude of guidelines.

\section{Unavailability of land}

Unavailability of land is the biggest housing delivery constraint in EMM because of dolomite and shallow undermining (Dyantyi 2007:80). This is confirmed by City of Ekurhuleni Annual Report (2011/12:189) which states that a total surface area of the EMM area of jurisdiction is underlain by dolomite land that needs to be managed, controlled and developed in accordance with current legislation to prevent the formation of sinkholes and substances that can have a detrimental impact on infrastructure and human life. In agreement with the foregoing, Ekurhuleni Metropolitan Municipality - IDP \& SDBIP (2015) states that the current housing backlog (144 000) and the housing solution (one house per stand) targeting poor families is constrained by land unavailability because most of the City's land is on 
dolomite, some undermined and others with serious natural and environmental constraints. The situation is further aggravated by the fact that a $28 \%$ customer growth (237 067 new customers) is expected up to 2025 (City of Ekurhuleni Annual Report 2010/11:25). While the Housing Development Agency is intended to help with the acquisition and release of land, as well as the provision of funding and the unblocking of delivery constraints and it will also seek to make a wider range of housing choices available including affordable, welllocated rental housing (Jeffery 2010:354), the unavailability of land poses a major insurmountable challenge (City of Ekurhuleni Annual Report 2010/11:25). Alternatives can however be made where flats can be built on the limited land available to help arrest the problem.

\section{Conclusion}

Informal settlements in urban areas are inevitable phenomena. As long as EMM offers economies of scale and an agglomeration economy, it will always continue to grow, attracting migrants from rural and other urban areas, leading to continued sprouting of informal settlements. This article confirms that government policies, population growth (including migration, urbanisation and demographics), municipal administrative issues and economic variables are the major causes of informal settlements. With EMM attracting hundreds of new residents every year in search of work and a better life including health facilities, medical services, education and social security, the housing backlog coupled with a shortage of housing subsidies means that for many people, there is no alternative but to live in informal housing particularly shack settlements. As Richards, O'Leary and Mutsonziwa (2007:375) put it, informal settlements are therefore here to stay for the next decade and beyond.

\section{Acknowledgemnets}

This article is a follow-up to the previously published work: 'Obstacles to housing delivery in Ekhurhuleni Metropolitan Municipality: A critical review of output and input', published in APSDPR, Volume 3, Issue 4, 2015.

\section{Competing interest}

The author declares that he has no financial or personal relationships which may have inappropriately influenced him in writing this article.

\section{References}

A'bear, T., 2012, 'Anchorville gets that sinking feeling', The South African Institute for Engineering and Environmental Geologists Journal 11(1), pp. 6-7.

Ademiluyi, I. A., 2010, 'Public housing delivery strategies in Nigeria: A historical perspective of policies and programmes', Journal of Sustainable Development in Africa 12(6), pp. 153-159.

ANC, 1994, Reconstruction and development programme (RDP) - A policy framework Umanyano Publications, Johannesburg.

Ayedun, C. A. \& Oluwabi, A. O., 2011, 'Issues and challenges militating against the sustainability of affordable housing provision in Nigeria', Business Management Dynamics 1(4), pp. 7-10

Baloyi, B. V., 2007, Housing delivery in South Africa - A project management case study, viewed 3 January 2013, from https://ujdigispace.uj.ac.za/handle/ $10210 / 4425$
Barry, M., 2003, 'Peri-urban tenure management in South Africa', Marrakeck 2(5), pp. 2.

Bhorat, H. \& Cassim, R., 2004, 'How can the South African engine become a Ferrari?', Special Report 28(2), pp.121-124

Bond, P., 2002, Unsustainable South Africa - Environment, development and social protest, Merlin Press, London.

Bond, P. \& Tait, A., 1997, 'The failure of housing policy in post-apartheid South Africa', Urban Forum 8(1), pp. 18-21.

Bonner, P., Nieftagodien, N. \& Mathabatha, S., 2012, Ekurhuleni - The making of an urban region, Wits University Press, Johannesburg.

Bradley, G., 2003, 'Housing', Black Business Quarterly 6(3), pp. 85.

Brutus, D., 2002, Cost recovery and the crisis of service delivery in South Africa, Human Sciences Research Council Publishers, Cape Town.

Burger, J., 2010, The reason behind service delivery protests in South Africa, viewed 4 June 2011, from http://www.polity.org.za/article

Carrington, D., 2015, World population to hit $11 \mathrm{bn}$ in 2100 - with $70 \%$ chance of continuous rise, viewed 27 November 2015, from http://www.geohive.com/ earth/population_now.aspx

Carter, R., 1990, Urban and rural settlements, Longman Group UK Limited, England.

City of Ekurhuleni Annual Report, 2010/11 EMM human settlements, City of Ekurhuleni, Germiston. pp. 25.

City of Ekurhuleni Annual Report, 2011/12 EMM human settlements, City of Ekurhuleni, Germiston. pp. 97-101.

City of Ekurhuleni, 2011, A ten year history of Ekurhuleni - Housing, 2011, City of Ekurhuleni, Germiston, pp. 16

Cloete, F., 1995, Local government transformation in South Africa, J.L. Van Schaik Publishers, Pretoria.

Cloete, J. J. N., 1997, South African Municipal government and administration, J.L. Van Schaik, Pretoria.

Cloete, F. \& Mokgoro, J., 1995, Policies for public service transformation, Juta and Company Limited, Cape Town.

Craythorne, D. L., 1993, Municipal administration, 3rd edn., Juta and Company Limited, Cape Town

Datt, R., 2002, The human development and economic development, Deep and Deep Publications (Pvt) Ltd, New Delhi.

Deedee, M., 2011, Gauteng government uses dolomite as reason to evict, South African SDI Alliance, Johannesburg.

Department of Housing, 2004, Breaking new ground: A comprehensive plan for the development of sustainable human settlements, Department of Housing, Pretoria.

Du Toit, G. S., Erasmus, B. J. \& Strydom, J. W., 2007, Introduction to business management, 7th edn., Oxford University Press, Cape Town.

Dyantyi, Q. R., 2007, 'A place to call home', Black Business Quarterly 33(3), pp.71.

Eddy, G., 2010, 'Fast Facts - South African Institute of race relations', Economic Growth and Education Are the Keys 9(1), pp. 12-18.

Ekurhuleni Metropolitan Municipality - Intergrated Development Plan and Service Delivery Budget Implementation Plan, 2013/14, City of Ekurhuleni, Germiston.

Ekurhuleni Metropolitan Municipality - Intergrated Development Plan and SDBIP Service Delivery Budget Implementation Plan, 2015, City of Ekurhuleni, Germiston.

Fife, I. 2007, 'Property inequality - Entry denied'. Financial Mail 192(9): August 24.

Giddings, S. W., 2007, Housing challenges and opportunities in Sub Saharan Africa, International housing coalition, Washington, DC.

Hablemitoglu, S., Ozkan, Y. \& Purutcuoglu, E., 2010, 'The assessment of the housing in the theory of Maslow's hierarchy of needs', European Journal of Socia Sciences 16(2), p. 3.

Harrison, B., 2013, 'No hope for Ekurhuleni's housing backlog', Germiston City News, 18 July.

Harvey, J., 2000, Urban land economies, 5th edn., Palgrave Publishers, New York.

Innes, D., Kentridge, M. \& Perold, H., 1992, Power and profit - politics, labour and business in South Africa, Oxford University Press, Cape Town.

Jeffery, A., 2010, Chasing the rainbow - South Africa's move from Mandela to Zuma, Art Publishers, Cape Town.

Jiboye, A. D., 2009, 'The challenges of sustainable housing and urban development in Nigeria', Journal of Environmental Research and Policies 4(3), pp.12-14..

Khan, F. \& Thring, P., 2003, Housing policy and practice in post-apartheid South Africa, Heinemann Publishers (Pty) Ltd, Sandown.

Knight, R., 2002, 'The black dispossession in South Africa - The myth of Bantustan independence', Southern Africa Perspectives \& Africa Fund 4(2): October.

Lindsell, D., 2007, 'A place to call home - Enabling dignified communities', Black Business Quarterly 33(3), p. 48.

Malpass, P., 1990, The housing crisis, Routledge, London.

Masilela, E., 2012, 'Rationale and challenges in delivering affordable housing in South Africa', IHC Conference, Johannesburg Country Club, Johannesburg, 3 October 2012

May, J., Carter, M. \& Padayachee, V., 2004, 'Is poverty and inequality leading to poor growth', South African Labour Bulletin 28(2), pp. 18-20.

Mhone, G. \& Edigheji, O., 2003, Governance in the new South Africa - The challenges of globalisation, University of Cape Town Press, Lansdowne. 
Musewe, T., 2012, 'Housing our people: Developing adequate housing for Africans,' Mobilitate 15(5), p. 37

Napier, M., 1993, 'Housing problem in South Africa - Ideological perspectives', Forum 2(1), p. 8.

Nathan, O., 2013, 'Building revolutionary working class counter power: Municipalities, service delivery and protest', Zabalaza, 19 March.

PADCO, 2006, 'Essential to economic, social and civic development', Housing for All $1(1)$, p. 1.

Power, A., 1993, Hovels to high rise - State housing in Europe since 1850, Routledge Publishers, London.

Provincial budgets and expenditure review, 2010, 2003/04 - 2009/10, Housing Government Printers, Pretoria, pp. 69-72.

Richards, R., O'Leary, B. \& Mutsonziwa, K., 2007, 'Measuring quality of life in informal settlements in South Africa', Subjective, Wellbeing and Security Journal 81(2), 375-388.

Robbins, S., Bergman, R., Stagg, I. \& Coulter, M., 2008, Management, 5th edn., Pearson Education, Australia.

Setplan, 2008, Densification framework - status quo: Analysis and findings document for Ekurhuleni Metropolitan Municipality, Settlement Planning Services, Johannesburg. pp. 38-68.

Sokupa, T., 2009, 'Let us have better coordination of inter-governmental relations', The Transformer 1(1), p.7

South Africa Survey 2008/9, 2009, Living conditions and communications - Housing South African Institute of Race Relations, Johannesburg.

South Africa year book, 2012/13, Human settlements, Government Printers, Pretoria pp. 19.

Srinivas, H., 1991, 'Viability of informal credit to finance low-income housing: Case study of three squatter settlements in Bangalore, India', unpublished Master's thesis report, Division of Human Settlements Development, Asian Institute of Technology, Bangkok.
Steenekamp, T., 2012, The South African economy, Oxford University Press, Cape Town.

Stoner, J. A. F., Freeman, A. E. \& Gilbert, D. A., 1995, Management, 6th edn., Prentice Hall International, Canada.

Storie, M., 2011, ‘Developing a physical vulnerability curve for low income settlements on dolomite in the Gauteng City-Region of South Africa', in Global Change and Stability Research Institute, University of Witwatersrand, Johannesburg, pp. 25-31.

Streek, B., 2001, Housing shortage still desperate, viewed 4 June 2011, from http:// $\mathrm{mg}$.co.za/article/2001-06-29-housing-shortage-still-desperate

The Housing Development Agency, 2013, Informal settlements status, Government Printers, Pretoria.

Tshitekere, C., 2008, 'The importance of adequate housing', Mail and Guardian, October.

UN-Habitat, 2015, Informal settlements, Report 31 May 2015, Routledge, Taylor and Francis Group, New York.

United Nations Centre for Human Settlements (Habitat) and International Labour Organization (ILO), 1995, Shelter provision and employment generation, ILO Publication, Nairobi.

University of Dublin, Trinity College, 2015, Slums and informal settlements, viewed 26 November 2015, from www.tcd.ie/Economics/Development_studies/link. php?ld=92

Van der Waldt, G. \& Du Toit, D.F.P., 1997, Managing for excellence in the public sector Juta and Company Limited, Kenwyn.

Weeks, J.R., 2012, An introduction to population - an international edition, 11th edn., Wadsworth Cengage Learning, Canada.

White paper on housing, 1994, A new housing policy and strategy for South Africa, Government Printers, Pretoria, pp. 1-55.

Zanganeh, M., Varesi, H. R. \& Zangiabadi, A., 2013, 'Strategic housing planning through sustainable development approach in Iran Metropolitans: Case study of Metropolitan Mashhad', Journal of Basic and Applied Scientific Research 3(9), p. 52 